\section{The dynamics of the production of AIDS-related stigma among pregnant women living with HIV/AIDS in Rio de Janeiro, Brazil}

\author{
A dinâmica da produção de estigma relacionado \\ à AIDS entre gestantes vivendo com HIV/AIDS \\ no Rio de Janeiro, Brasil
}

\author{
La dinámica en la generación del estigma, relacionado \\ con el SIDA, entre gestantes viviendo con \\ $\mathrm{VIH} / \mathrm{SIDA}$ en Río de Janeiro, Brasil
}

Simone Monteiro 1

Wilza Villela 2

Livia Fraga 1

Priscilla Soares 1

Adriana Pinho 1

doi: 10.1590/0102-311X00122215

\begin{abstract}
The study analyses the relationship between AIDS-related stigma and the processes of discrimination prior to diagnosis among pregnant women living with HIVIAIDS. The fieldwork involved interviews about the life trajectories of 29 pregnant women living with HIVIAIDS, recruited at two AIDS services in Rio de Janeiro, Brazil. The analysis revealed that before HIV diagnosis, social and gender inequalities experienced by these women reduced their access to material and symbolic goods that could have enhanced educational and career prospects and their ability and autonomy to exercise sexual and reproductive rights. Being diagnosed with HIV triggered fear of moral judgment and of breakdown in social and family support networks. Given these fears, pregnant women living with HIVIAIDS opt for concealment of the diagnosis. It is necessary for health services, NGOs and government agencies to work together to face the factors that fuel stigma, such as socioeconomic and gender inequalities, taboos and prejudices related to sexuality, and also develop actions to enable women to redefine the meaning of the disease.
\end{abstract}

Acquired Immunodeficiency Syndrome; Social Stigma; Pregnant Women

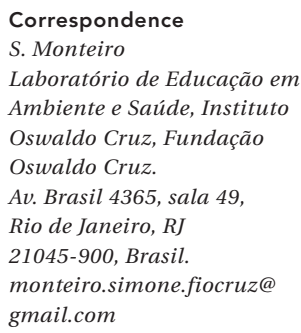




\section{Introduction}

The current state of the global HIV/AIDS epidemic confirms the importance of medical advances aimed at prolonging life expectancy and increasing quality of life among people already infected with the disease, and at preventing new cases. However, the reach of antiretroviral therapy (ART) will remain limited unless this treatment is integrated with sociopolitical and structural interventions to ensure access to early diagnosis and treatment. Such interventions include measures to reduce the stigma attached to AIDS, which other research has recognized to be a factor that prevents many people from seeking appropriate treatment 1 .

Goffman 2 proposed that stigma is a socially undesirable mark or attribute. Based on a critical analysis of the appropriation of this concept by the health field, this work assumes that the production of stigma is not inherently rooted in social interactions and is not restricted to assigning negative characteristics to people who have the disease. We suggest that stigma is part of a social process that hinders access to material and symbolic goods among stigmatized groups (including information, use of resources and health care), and that governments and other actors should tackle it through micro and macro structural interventions 3,4 .

From this perspective, in order to understand the dynamics of the production and reproduction of the stigma attached to HIV/AIDS, we must identify the characteristics of the process of hierarchization and inequalities within certain sociocultural contexts and their impact on access to health services among given population groups. This study therefore aims to understand the relationship between AIDS-related stigma and the social processes that result in discrimination prior to diagnosis among pregnant women living with HIV/AIDS in Rio de Janeiro, Brazil.

The focus of this study is related to vertical transmission prevention and control policy that has been in effect in Brazil since 1996 and centers on promoting HIV testing during pregnancy and delivery. These tests account for over half of the AIDS diagnoses among women in the country 5 . According to national guidelines, pregnant women infected with HIV/AIDS are referred to specialized facilities for clinical monitoring and treatment to prevent HIV perinatal transmission 6,7 . This study is part of a wider project addressing stigma, gender and reproductive trajectories conducted with users of AIDS services and their partners that was carried out in Rio de Janeiro with the support of the Rio de Janeiro State Research Foundation (FAPERJ).

\section{Methodology}

The methodological approach adopted by this study is founded on the contributions of social science research addressing the meanings assigned to health and disease by different social groups 8,9 . By focusing on the subjective and interpretative aspects of social life, social anthropology plays an important role in the analysis of the relationship between cultural systems, social hierarchies and access to material and symbolic goods within the context of the social and health behaviors of individuals and social groups. This approach is consistent with the aim of analyzing the dynamics of the production of stigma from a socioeconomic and gender inequality perspective.

The study was conducted in two health care services that offer ART, prevention of HIV perinatal transmission, and guidance on the relationship between adherence to treatment and the increase in the chances of survival of mother and child. The services have a multidisciplinary team (an infectious disease specialist, obstetrician, psychologist, nursing technician and social worker) and develop clinical trials in partnership with national and international organizations, allowing the center to increase the size of its team, exchange updated information and provide training for its health professionals. One of the services is located in the Rio de Janeiro city center and treats residents from any of the city's neighborhoods, while the other is in the city's metropolitan area and offers treatment to residents in various neighboring municipalities.

The pregnant women living with HIV/AIDS were recruited randomly after a previous contact in the services' waiting room, during different days of the week, by three authors of the study (A.P., P.S., L.F.). They explained the main objective of the study and invited them to participate. The research team carried out nine months of field work during the course of 2013 and this involved observation in the services' waiting room and individual interviews with 29 pregnant women living with HIV/AIDS (15 from one service and 14 from the other) in a private room at the health service to obtain information about the following: socioeconomic status, level of schooling and work history, sexual and reproductive health experiences, health service access, discrimination, violence and social support.

Inclusion criteria included being pregnant, being diagnosed as being HIV-positive, over 18 years of age, a user of the health care service and agreeing to sign the informed consent form. Three researchers (L.F., P.S., A.P.) carried out recorded interviews lasting between one and one- 
and-a-half hours on an individual basis in treatment rooms.

Previous contacts with some health professionals of the two services investigated as well as epidemiological data regarding AIDS among women in Brazil 5 suggest that the background of the women interviewed was similar to what the research team observed in the waiting rooms. It is important to also highlight that according to national guidelines ${ }^{6}$ pregnant women receive diagnoses of HIV infection during pregnancy or birth at the primary care services and are referred to prevention of mother-to-child HIV transmission public services, such as the ones investigated.

The Ethics Research Committee of the Oswaldo Cruz Institute, Oswaldo Cruz Foundation (CAAE 07820512.0.0000.5248) and of the facilities involved in the study approved the project.

The researchers analyzed the results of the interviews using the social meaning interpretation method to identify: the impacts of socioeconomic and gender inequality on living conditions, level of schooling and work, sexual and reproductive health experiences, and access to material and symbolic goods; and also to understand how HIV-related stigma manifested itself and influenced the daily life of the women after they learned they had HIV. The analysis comprised the following steps: transcription and thorough reading of the interviews; definition and organization of categories of analysis; and interpretation of the information considering the research objectives, theoretical framework and literature 10 .

The results were grouped into two areas: socioeconomic inequality and gender inequality and their effects on the life trajectories of women before they were diagnosed as HIV-positive; and the women's reactions to being diagnosed as HIVpositive and how they managed HIV/AIDS.

\section{Results}

Socioeconomic inequality and gender inequality and the life trajectories of women before being diagnosed as HIV-positive

As indicated in Table 1, the 29 women interviewed for this study were aged between 19 and 39 years and the majority (24) had a permanent partner. Thirteen said they were brown, ten said they were black and six identified as white. With regard to family income, 12 women lived on up to twice the minimum wage and 10 on between twice and four times the minimum wage (10/29), while seven did not inform their family income and said they were financially dependent on their partner or family. These figures in- clude social support, such as the Bolsa Família (Family Grant), received by seven women, financial assistance related to health problems, and unemployment benefits, received by four women. Most of the interviewees lived in the neighborhood where they were born and remained in the same socioeconomic class into which they were born.

A third of the women (10/29) had not completed primary school and had less than eight years of schooling, $20 \%(6 / 29)$ had completed primary school, and less than half (13/29) had completed secondary school (12 years of study). Various interviewees demonstrated difficulties in reading the informed consent form and understanding the interview questions. Factors that led women to abandon school included becoming pregnant, the need to work to support themselves and their family, and adherence to traditional gender roles, whereby the woman's partner decides that she should stay at home, as shown by the following accounts. The accounts include the initials and the age of the interviewees. Further information can be found in Table 1.

"I gave up studying when I was 13. I had to stop because my mom became ill, and I had younger brothers and sisters... My dad abandoned us... as I was the oldest daughter, I had to take on a lot of responsibility, you know" (VS, 39).

"My husband didn't like me going to school. He said I was involved with the people there; that I was unfaithful to him at school... so I stopped. I left it all behind" (YC, 20).

Apart from the relationship between poverty and gender inequality, the accounts reveal evidence of family breakdown, including material and affective abandonment by parental figures, and taking on domestic responsibilities to the detriment of education, as can be seen from the following accounts:

“What was your parents' relationship like? Horrible; they used to fight, hit each other, call the police. Neighbors... I don't have very good memories really" (AG, 39; author's emphasis).

"(...) well, I only live with my mother, you know. My mom brought us up by herself (...). She had to work to support us, so school didn't really come into it... she had to work, I had a brother to look after. I'm one of seven children" (FD, 24).

Half of the interviewees reported cases of psychological, physical and/or sexual violence within the family of origin and in the marital relationship:

"Had you ever suffered [from physical violence] before? Of course... I was beaten a lot. My ex-stepfather liked to hit me (...) I was sexually abused too... by a neighbor who said he was going to be my godfather" (MS, 25; author's emphasis). 
Table 1

Data regarding the 29 pregnant women living with HIV/AIDS interviewed.

\begin{tabular}{|c|c|c|c|c|c|c|c|c|c|c|}
\hline Initials & Age & Color & $\begin{array}{c}\text { Years of formal } \\
\text { education }\end{array}$ & Occupation & $\begin{array}{l}\text { Number of } \\
\text { minimum } \\
\text { wage * }\end{array}$ & Social welfare & $\begin{array}{l}\text { Current } \\
\text { partner's HIV } \\
\text { status }\end{array}$ & $\begin{array}{c}\text { Number } \\
\text { of children } \\
\text { born }\end{array}$ & $\begin{array}{l}\text { HIV diagnosis } \\
\text { during current } \\
\text { prenatal care }\end{array}$ & $\begin{array}{c}\text { Via of } \\
\text { infection }\end{array}$ \\
\hline MS & 25 & Brown & 12 & Housewife & $2-4$ & No & HIV- & 0 & Yes & $\begin{array}{c}\text { Heterosexua } \\
\text { relation }\end{array}$ \\
\hline $\mathrm{AP}$ & 38 & Black & 12 & Housewife & $2-4$ & No & $\mathrm{HIV}+$ & 6 & No & $\begin{array}{c}\text { Heterosexua } \\
\text { relation }\end{array}$ \\
\hline DP & 27 & Brown & $<9$ & Housewife & $\leq 2$ & Health care aid & $\begin{array}{l}\text { Without } \\
\text { partner }\end{array}$ & 2 & Yes & $\begin{array}{c}\text { Heterosexua } \\
\text { relation }\end{array}$ \\
\hline RG & 19 & Brown & 12 & Housewife & $2-4$ & Family grant & $\begin{array}{l}\text { Without } \\
\text { partner }\end{array}$ & 0 & No & $\begin{array}{c}\text { Heterosexua } \\
\text { relation }\end{array}$ \\
\hline TS & 19 & Brown & $9-11$ & Housewife & $\leq 2$ & No & HIV- & 0 & No & $\begin{array}{c}\text { Vertical } \\
\text { transmission }\end{array}$ \\
\hline LS & 33 & Black & $<9$ & Housewife & $2-4$ & Family grant & $\mathrm{HIV}+$ & 2 & No & $\begin{array}{c}\text { Heterosexua } \\
\text { relation }\end{array}$ \\
\hline VL & 30 & White & $9-11$ & Housewife & $2-4$ & Family grant & HIV- & 2 & Yes & $\begin{array}{c}\text { Heterosexua } \\
\text { relation }\end{array}$ \\
\hline SG & 35 & Brown & $9-11$ & Housewife & $\leq 2$ & No & $\mathrm{HIV+}$ & 2 & No & $\begin{array}{c}\text { Heterosexua } \\
\text { relation }\end{array}$ \\
\hline FD & 24 & Brown & $<9$ & Housewife & $\mathrm{NI}$ & No & Unknown & 0 & No & $\begin{array}{c}\text { Heterosexua } \\
\text { relation }\end{array}$ \\
\hline RV & 38 & Brown & $9-11$ & Seamstress & $2-4$ & Family grant & Unknown & 4 & No & $\begin{array}{c}\text { Heterosexua } \\
\text { relation }\end{array}$ \\
\hline FS & 30 & Black & $<9$ & Housewife & $\mathrm{NI}$ & No & $\mathrm{HIV}+$ & 0 & Yes & $\begin{array}{c}\text { Heterosexua } \\
\text { relation }\end{array}$ \\
\hline VB & 26 & Brown & 12 & Housewife & $\leq 2$ & No & $\mathrm{HIV}+$ & 0 & No & $\begin{array}{c}\text { Heterosexua } \\
\text { relation }\end{array}$ \\
\hline $\mathrm{RP}$ & 27 & Brown & 12 & Housewife & $\leq 2$ & $\begin{array}{l}\text { Maternity } \\
\text { insurance }\end{array}$ & Unknown & 4 & No & $\begin{array}{c}\text { Heterosexua } \\
\text { relation }\end{array}$ \\
\hline$A G$ & 39 & Black & 12 & $\begin{array}{l}\text { Supermarket } \\
\text { checkout girl }\end{array}$ & $2-4$ & No & HIV- & 0 & No & $\begin{array}{c}\text { Heterosexua } \\
\text { relation }\end{array}$ \\
\hline MN & 24 & White & 12 & Housewife & $\leq 2$ & No & $\mathrm{HIV+}$ & 0 & Yes & $\begin{array}{c}\text { Heterosexua } \\
\text { relation }\end{array}$ \\
\hline CG & 24 & White & 12 & Housewife & $\leq 2$ & No & HIV- & 0 & No & $\begin{array}{c}\text { Heterosexua } \\
\text { relation }\end{array}$ \\
\hline NR & 23 & Black & 12 & $\begin{array}{c}\text { Sales counter } \\
\text { personnel }\end{array}$ & $\leq 2$ & No & Unknown & 0 & Yes & $\begin{array}{c}\text { Heterosexua } \\
\text { relation }\end{array}$ \\
\hline MD & 32 & Brown & $<9$ & Housewife & $\leq 2$ & Family grant & Unknown & 6 & No & $\begin{array}{c}\text { Heterosexua } \\
\text { relation }\end{array}$ \\
\hline SC & 30 & Brown & $9-11$ & Housewife & $\mathrm{NI}$ & No & $\begin{array}{l}\text { Without } \\
\text { partner }\end{array}$ & 3 & Yes & $\begin{array}{c}\text { Heterosexua } \\
\text { relation }\end{array}$ \\
\hline CS & 20 & Brown & 12 & Housewife & $\leq 2$ & $\begin{array}{c}\text { Unemployment } \\
\text { insurance }\end{array}$ & HIV- & 0 & No & $\begin{array}{c}\text { Vertical } \\
\text { transmission }\end{array}$ \\
\hline RG & 28 & Brown & $<9$ & Housewife & $2-4$ & No & HIV- & 0 & No & $\begin{array}{c}\text { Heterosexua } \\
\text { relation }\end{array}$ \\
\hline SO & 35 & Black & $<9$ & Housewife & $\leq 2$ & No & $\mathrm{HIV}+$ & 4 & No & $\begin{array}{c}\text { Heterosexua } \\
\text { relation }\end{array}$ \\
\hline MC & 25 & White & 12 & Housewife & $\leq 2$ & No & HIV- & 0 & No & $\begin{array}{c}\text { Heterosexua } \\
\text { relation }\end{array}$ \\
\hline$A E$ & 35 & White & 12 & Housewife & $\mathrm{NI}$ & Retired ** & HIV- & 1 & No & $\begin{array}{c}\text { Heterosexua } \\
\text { relation }\end{array}$ \\
\hline
\end{tabular}

(continues) 


\begin{tabular}{|c|c|c|c|c|c|c|c|c|c|c|}
\hline Initials & Age & Color & $\begin{array}{c}\text { Years of formal } \\
\text { education }\end{array}$ & Occupation & $\begin{array}{l}\text { Number of } \\
\text { minimum } \\
\text { wage * }\end{array}$ & Social welfare & $\begin{array}{c}\text { Current } \\
\text { partner's HIV } \\
\text { status }\end{array}$ & $\begin{array}{c}\text { Number } \\
\text { of children } \\
\text { born }\end{array}$ & $\begin{array}{l}\text { HIV diagnosis } \\
\text { during current } \\
\text { prenatal care }\end{array}$ & $\begin{array}{c}\text { Via of } \\
\text { infection }\end{array}$ \\
\hline VA & 28 & Black & $9-11$ & Housewife & $\mathrm{NI}$ & Family grant & HIV- & 4 & No & $\begin{array}{c}\text { Heterosexual } \\
\text { relation }\end{array}$ \\
\hline$A C$ & 20 & Black & 12 & Housewife & $\mathrm{NI}$ & No & $\begin{array}{l}\text { Without } \\
\text { partner }\end{array}$ & 0 & Yes & $\begin{array}{c}\text { Heterosexual } \\
\text { relation }\end{array}$ \\
\hline YC & 20 & White & $<9$ & Store manager & $2-4$ & No & Unknown & 0 & Yes & $\begin{array}{c}\text { Heterosexual } \\
\text { relation }\end{array}$ \\
\hline VS & 39 & Black & $<9$ & Housewife & $2-4$ & Family grant & $\mathrm{HIV+}$ & 3 & No & $\begin{array}{c}\text { Heterosexual } \\
\text { relation }\end{array}$ \\
\hline JV & 21 & Black & $<9$ & Housewife & $\mathrm{NI}$ & No & Unknown & 0 & Yes & $\begin{array}{c}\text { Heterosexual } \\
\text { relation }\end{array}$ \\
\hline
\end{tabular}

* In 2015 the minimum monthly wage in Brazil is around US\$ 250 (BRL 788);

** Disability retirement brought on by HIV.

"We had a good relationship... but he was really jealous of me, and didn't let me go out... he physically abused me sometimes... hit me... was jealous of me... he used to drink .. and he became even more aggressive" (FS, 30).

Many of the interviewees started to work during adolescence. However, low levels of schooling led to a precarious insertion into the labor market in occupations that require few qualifications, have little prestige, pay low salaries, and have a high turnover, such as shop assistants, cashiers, maid, cleaner, and manicurist. It should be highlighted that women doing low-paid jobs that require few qualifications is one of the characteristics of the labor market in Brazil (Institito Brasileiro de Geografia e Estatística. Estatísticas de gênero, 2014. http://spm.gov.br/assuntos/es tatisticas-de-genero, accessed on 08/Jun/2015).

At the time the interviews were conducted, most of the women (23/29) were carrying out only domestic tasks, either because it was imposed on them or suggested by their partners, or because they were pregnant or suffering the side effects of the ART. Lack of financial independence, partner pressure and the symbolic value of motherhood mean that women are more likely to remain at home and look after the house and children than men. Problems arise when the relationship breaks down and the woman is forced to appeal to her family for help, as the following account shows:

“My [ex] husband didn't want me to work [...] And what kind of help and support did you receive during the separation? From my brothers and sisters. They gave me a lot of support. I left my house ... (...) I gave everything up. The only thing I took with me was my children, their clothes and my TV. I left the rest there, I didn't want anything. (...) I went to my sister's house" (VS, 39; author's emphasis).

Poverty and the various manifestations of gender inequality that marked the schooling and work life of these pregnant women living with HIV/AIDS resulted in a lack of access to health services and to knowledge that promotes autonomy in sexual and reproductive decision-making. The case of 21-year-old JV illustrates this: despite having two miscarriages in the seventh month of pregnancy, the cause (described as "thrombosis") was only investigated after she was diagnosed as being HIV-positive during pregnancy.

Most of the women (24) confirmed irregular or no use of contraceptive methods. Despite easy access to condoms, the negotiation of their use with partners was by no means easy. Many refused to use them, especially after the relationship had been cemented, and many women ended up accepting the situation due to the bonds of trust between the couple and lack of concern with STI/ AIDS prevention. Of the 22 pregnant women who were unaware that they had AIDS before pregnancy or delivery, the majority (16) confirmed that they did not make regular use of contraceptive methods, despite not trying to become pregnant at the time.

Family support, generally provided by women (mothers, grandmothers, mothers-in-law, sisters, cousins, and sisters-in-law), can alleviate financial and material difficulties. This kind of support generally takes the form of a place to stay, help in bringing up the children, and/or financial support. Although welcome, this kind of support is often limited because those providing it often have limited financial means as well. 
Learning you are HIV-positive and living

with the AIDS-related stigma: tensions

and negotiations

Approximately half of the interviewees (15) were expecting their first child at the time of the study, and the majority learned they were HIV-positive during pregnancy (13 during the current pregnancy and seven in the previous pregnancy). Two were informed after delivery and five took the test because of doubts about their or their partners' (3) health, or because they donated blood (2). Two were born with the virus and learned they were HIV-positive during adolescence. After being diagnosed, generally through a primary health care facility, the women were referred to public health services to prevent mother-to-child transmission. None of the interviewees had taken a test prior to diagnosis or had even considered the possibility of being infected, as the following account illustrates " my god, if I hadn't got pregnant I would have never found out" (RG, 19).

Although most of the women had received information about HIV prevention, they used condoms on a rather irregular basis, either because of their partners' refusal to use them, or because they were not fully aware of the risks of infection. Since they did not have contact with groups historically linked to the HIV/AIDS epidemic (gay men, drug users and female sex workers), the test was not considered important and the diagnosis came as devastating surprise:

"You wonder; why did it happen to me... because I think, if you are part of, you know, 'ah, I inject drugs', 'ah, I'm a prostitute', you know that if you don't take precautions you'll get it. But when you're a housewife, a woman, a wife etc., and this happens, you feel shattered" (VL, 30).

The diagnosis triggers a number of fears: of dying and not being able to look after the children; of being discriminated against and abandoned by your partner and by the family; and of stigma. A fatalistic view of the disease also leads to difficulty in coming to terms with the diagnosis and reluctance to seek health services.

"Ididn'twant tocome. (...) Fearofprejudice, that people would realize. (...) Of people, I don't know, looking at me and pointing the finger: 'Look at her, look at her, she's ill'. 'I bet she got off with a load of men and that's why she got the disease' (...). Then, after the first time I came here (...) I spoke to doctor $R$ and he said: 'you have had this illness for a little over a year. Why didn't you come before?'. I said that there was no point in coming here to take medication because I was going to die anyway" (SG, 35).

Even an interviewee who had been a sex worker was not aware of the risk of being infected and was surprised with the result of the test done during delivery: "the doctor told me I had it, and I couldn't believe it. I asked him not to tell anyone; not even my mom and dad or Maria's dad. Not even him" (DP, 27).

Although access to ART and counseling contributed to redefining the meaning of AIDS, whereby the women began to see it as a treatable problem rather than a fatal disease, it did not reduce the fear of stigma. Concealing the diagnosis from people was a common form of dealing with the stigma: "you hide everything, medicines without labels, tests, papers and everything, in a shoebox locked away in the cupboard" (LS, 33). It is important to highlight here the role played by the health service in helping women to conceal the diagnosis, in some cases advising them to avoid questions from family members and friends about the fact they are not breast-feeding, for example.

The management of the disease also affects social life, as patients distance themselves from friends and family and social activities as the following account illustrates: "I prefer to distance myself from everyone, even my own family, because if these people knew they would distance themselves from me" (JV, 21). The fear of publicly revealing the diagnosis is also illustrated by the account of the only woman to have gone to an NGO that works with people living with HIV/ AIDS: "There was this group I went to, an NGO for people who have tested positive for HIV. I thought it was good... but when I arrived, I saw my neighbor and never went back" (LS, 33). Although this neighbor could have helped her to interact with the group, it is possible that the fear of being identified prevented her from benefiting from the support offered by the NGO.

The fear of being pitied is another factor that leads people living with HIV/AIDS to conceal the diagnosis, since people from their social network share the same fatalistic view of the disease that they had before being diagnosed: "I don't like people pitying me. I'm not a cripple (...) since they know nothing about it they will think I am dying" (LS, 33); “(...) I couldn't stop thinking that people would feel pity for me, that my family would pity me (...) 'ah, poor little D'” (DP, 27).

Some women had difficulty telling their partner about the diagnosis due to the fear of being abandoned, particularly if the partner did not have the virus: “(...) his test was negative, so I thought that ...that he would turn his back on $m e$ " (NR, 23). However, the women's partners were generally supportive, accompanying them during prenatal care and encouraging them to adhere to treatment.

The majority of women who were working when they found out they were HIV-positive 
feared that they would be made redundant if they revealed that they had the disease ("if I say I'm HIV-positive, the employer won't want me to stay on", RV, 38), or worried about the risk of transmitting the disease ("I was scared of giving the children at the daycare a bath (...) I thought that any bruise or bump, even where there was no blood, could contaminate someone... until I got it into my head that it wasn't like that. It took a while", RP, 27). None of the interviewees knew that, by law, a person cannot be made redundant because he or she is HIV-positive.

Few pregnant women living with HIV/AIDS said that they were able to talk to people outside their family and ask for advice or help related to health or other issues. The women did not seek public services before or after the diagnosis, apart from the state health and education systems and benefits mentioned above. Only one member of the sample sought legal support to obtain child support, while others sought support from friends and neighbors rather than seeking public or community support.

\section{Discussion}

The sample was composed predominantly of low-income, black and brown women, showing that this group is highly vulnerable to HIV/AIDS infection. As Slabbert et al. 11 suggest, the transfer of the HIV epidemic from the first to the third world was accompanied by a shift in focus; from gay white men, to poor (mainly black) women. The registered cases of AIDS among the female population in Brazil reveal that the disease is contracted predominantly through heterosexual transmission (96.9\%) and by low-income women with a low level of education 5 . This data suggests that, besides gender inequality, there is a complex relationship between poverty and low levels of education and vulnerability to HIV/AIDS infection among women 12,13.

The analysis of of these women's life trajectory reveals that they had already experienced some kind of discrimination before being diagnosed as HIV-positive. This resulted in a reduction of access to the material and symbolic goods that could have enhanced their education and career prospects, increased their ability to exercise sexual and reproductive rights and autonomy in affective and sexual relationships, and expanded their social support network; elements which improve coping with the stigma attached to HIV/AIDS, understood as getting on with life and making plans regardless of the disease 14,15,16.

Being diagnosed as HIV-positive - in most cases during pregnancy - was a devastating sur- prise and triggered fear. These feelings can be partially explained by the misinformation that exists about HIV/AIDS based on fatalistic reactions and the belief that HIV is the consequence of deviant behavior 17. Testing during pregnancy is the main way of diagnosing the disease among women and accounts for $57 \%$ of HIV testing in this group. According to Brazilian Ministry of Health data $14.7 \%$ of women request tests spontaneously, while $2.9 \%$ seek tests due to risky behavior 5 , suggesting that, even years after the AIDS epidemic officially began, women generally feel that they are not at risk.

The fear of transmitting HIV to the fetus was an additional concern for these women. Although this kind of view has been redefined since the introduction of prevention of vertical HIV transmission, there is still a fear, outside the health care setting, that being diagnosed HIVpositive has a negative impact on life, be it on marriage, family relationships, friendships, or on work. The fear of moral judgment associated with AIDS stigma was further aggravated by a fear of breakdown in social and family support networks. As a result, concealing the diagnosis, otherwise defined as "stigma management", is one of the main strategies adopted by people diagnosed as HIV-positive to manage the disease in the face of stigma (or deteriorated identity) $18,19,20,21$.

According to Goffman 2, when the undesirable mark or attribute that leads to the stigma is invisible, one of the main strategies adopted by those wanting to avoid the stigma is the manipulation of information. The mark is concealed by the person suffering the stigma in order to manage and reduce the tension that arises from contact with so-called "normal people". In other words, in the face of the threat of losing credit or consideration, the individual seeks to "manage" any information that they consider could cause some form of harm, which can mean limiting or even giving up their social life, as illustrated by the accounts of pregnant woman living with HIV/AIDS discussed by Adam \& Herlich 22.

However, in the case of HIV/AIDS, basic citizen rights were achieved exactly because the issue was brought out into the open, particularly among gay men. The vindication of rights by demystifying the issue was also an important strategy in the case of mental illness 23 and cancer, the latter of which has been able to reduce many of the stigmas due to the advances in therapy and the visibility of cancer patients 24,25 . Although the law protects the confidentiality of HIV test results, the concealment of the condition not only hampers the fight against the stigma attached to HIV/AIDS, but also contributes to maintaining it. 
There is a difference between right to confidentiality and fear of revealing the diagnosis. It is possible to live with HIV and fully enjoy the benefits of the achievements gained in the field of rights of people living with HIV/AIDS, prevention measures and ART.

However, the reluctance of these pregnant women living with HIV/AIDS to reveal the diagnosis is understandable, given their life trajectories and current situation. As described above, the life of most of these women has been marked by high levels of social vulnerability, in which socioeconomic inequality and gender inequality have resulted in insufficient material and symbolic resources to deal with the supposed consequences of "unveiling" the diagnosis, such as being left by their partner, loss of family support and job loss. Fragile and limited affiliations and sources of support mean that the possibility of loss is a threat 26 .

It could be said that these women's fears of moral judgment is a consequence of the history of AIDS and its association with prostitution and, later, with women who are deceived and infected by unfaithful, and often bisexual, partners. In other words, the stigma associated with marginalized groups (sex workers, gay men, intravenous drug users), that historically were categorized as "risk groups" for AIDS, contributes to increase women's vulnerability to HIV who do not identify themselves with such groups. These findings indicate interactions between the production of AIDS-related stigma and other stigmas prior to the AIDS epidemic, related to structures and systems of social inequality, as discussed by Monteiro et al. 4 .

By not being involved in the processes of social mobilization and dialog that encourage the understanding of AIDS as a health problem that can affect anybody, regardless of their moral standing, the women interviewed by this study have embodied the stigma attached to this disease. Being part of a group that is subjected to derogatory treatment is disconcerting and experiencing the disease is not enough to stimulate attitudes that help to deconstruct the stigma.

During the course of the 1990s, the so-called "feminization of HIV" encouraged women to adopt prevention measures, based mainly on the development of negotiation skills with respect to condom use by a partner who could be HIV-positive. However, there was a notable reluctance among women to accept that their partners belonged to a high-risk group and refusal to use a condom by partners, ultimately for the same reasons. There have therefore been few advances in the discussion of the specificities of the stigma among wo- men, which raises questions over their sexual behavior and gender and social inequalities.

Considering that AIDS-related stigma should be faced by psychosocial, cultural and structural interventions, our findings indicate the need for a critical review of the actions and policies directed to women living with HIV/AIDS in Brazil. Such perspective implies that responses to HIV should recover the focus on human rights and on community participation 27,28 .

\section{Final considerations}

Despite being a cross-sectional study carried out in only two health care facilities, this study's findings allow us to reflect on the dynamics of the production of the stigma attached to HIV among women and offer some clues on how to cope with it. The results suggest that, among women, this stigma is intimately related to their life trajectory, showing that a combination of socioeconomic inequality and gender inequality prevents infected women from effectively coping with the stigma and continuing to enjoy their lives. Concealing the disease is the main coping strategy, but causes great anxiety and anguish. It is therefore important for health services, NGOs and government agencies committed to providing Brazil's response to the HIV/AIDS epidemic to acknowledge the importance of tackling this stigma so that people with AIDS may live not only longer, but also better.

Further efforts are needed to complement existing measures and create new strategies aimed at deconstructing this stigma in order to promote coping, including: the creation and implementation of policies to combat gender inequality and ensure equal access to material and symbolic goods; the promotion of greater access to information about HIV/AIDS among people infected with the disease; interventions to promote reflection by women infected with the disease on their lives and experiences of living with HIV/AIDS, to enable them to redefine the meaning of the disease, rather than merely conceal it. In this respect, health facilities that provide specialist services for pregnant women living with HIV/AIDS have a crucial role to play, since the majority of infected women learn that they have the disease during pregnancy and receive counseling and basic guidance on how to live with HIV. These women must decide whether to reinforce the stigma by concealing the diagnosis, or to confront it by assimilating the disease and incorporating the daily routines that the condition imposes. These are strategic decisions and, with the necessary support of broader policies, 
these health facilities are able to make a crucial contribution.

In summary, confronting the stigma attached to HIV/AIDS demands interventions at the individual and collective level. Combating the factors that fuel it, such as socioeconomic in-

\section{Contributors}

S. Monteiro and W. Villela participated in the project's coordination and developed the analysis and writing of the article. L. Fraga, P. Soares and A. Pinho developed the fieldwork and collaborated in the analysis and reviewing of the article.

\section{Acknowledgments}

The authors wish to thank Rio de Janeiro State Research Foundation (FAPERJ) and Brazilian National Research Council (CNPq) for their support as well as the women interviewed. equality and gender inequality, and taboos and prejudices related to sexuality, and developing specific individual actions to help women cope with living with HIV/AIDS, without constraints, are important steps forward at this stage of the epidemic.

\section{References}

1. Joint United Nations Programme on HIV/AIDS. The gap report 2014. http://www.unaids.org/sites/ default/files/media_asset/UNAIDS_Gap_report en.pdf (accessed on 08/Mar/2015).

2. Goffman E. Estigma: notas sobre a manipulação da identidade deteriorada. 4a Ed. Rio de Janeiro: LCT Editora; 1988.

3. Parker R. Stigma, prejudice and discrimination in global public health. Cad Saúde Pública 2012; 28:164-9.

4. Monteiro S, Villela W, Soares P. The interaction between axes of inequality in studies on discrimination, stigma, and HIV/Aids: contributions to the recent international literature. Glob Public Health 2013; 8:519-33.

5. Departamento de DST, Aids e Hepatites Virais, Secretaria de Vigilância em Saúde, Ministério da Saúde. Boletim Epidemiológico Aids/DST 2014; Ano III, no 01 .

6. Departamento de DST, Aids e Hepatites Virais, Secretaria de Vigilância em Saúde, Ministério da Saúde. Protocolo para a prevenção de transmissão vertical de HIV e sífilis. Brasília: Ministério da Saúde; 2010.

7. Departamento de DST, Aids e Hepatites Virais, Secretaria de Vigilância em Saúde, Ministério da Saúde. Recomendações para a profilaxia da transmissão vertical do HIV e terapia antirretroviral em gestantes: manual de bolso. Brasília: Ministério da Saúde; 2010.

8. Minayo MC. O desafio do conhecimento: pesquisa qualitativa em saúde. São Paulo: Editora Hucitec/ Rio de Janeiro: Abrasco; 1996.

9. Herzlich C. Saúde e doença no início do século XXI: entre a experiência privada e a esfera pública. Physis (Rio J.) 2004; 14:383-94.

10. Becker H. Sociological work: method and substance. Chicago: Adline; 1970.

11. Slabbert M, Knijn T, De Ridder D. Improving HIV prevention programs: the role of identity in shaping healthy sexual behavior of rural adolescents in South Africa. Vulnerable Child Youth Stud 2015; 10:93-103.

12. Garcia S, Sousa F. Vulnerabilidade ao HIV/Aids no contexto brasileiro: iniquidades de gênero, raça $\mathrm{e}$ geração. Saúde Soc 2010; 19 Suppl 2:9-20. 
13. Villela WV, Barbosa RM. Prevenção da transmissão heterossexual do HIV entre mulheres: é possível pensar estratégias sem considerar suas demandas reprodutivas? Rev Bras Epidemiol 2015; 18 Suppl 1:131-42.

14. Kumar S, Mohanraj R, Rao D, Murray K, Manhart L. Positive coping strategies and HIV-related stigma in south India. AIDS Patient Care STDS 2015; 29:157-163.

15. Turan J, Nyblade L. HIV-related stigma as a barrier to achievement of global PMTCT and maternal health goals: a review of the evidence. AIDS Behav 2013; 17:2528-39.

16. Faria E, Gonçalves T, Carvalho F, Lopes R, Piccinini C. Coping strategies among Brazilian pregnant women living with HIV. Paidéia (Ribeirão Preto) 2014; 57:67-74.

17. Bastos FI. Da persistência das metáforas: estigma e discriminação \& HIV/Aids. In: Monteiro S, Villela WV, organizadoras. Estigma e saúde. Rio de Janeiro: Editora Fiocruz; 2013. p. 91-103.

18. Silva NEK, Ayres JRCM. Estratégias para comunicação de diagnóstico de HIV a parceiros sexuais e práticas de saúde. Cad Saúde Pública 2009; 25:1797-806.

19. Renesto HM, Falbo A, Souza E, Vasconcelos MG. Enfrentamento e percepção da mulher em relação à infecção pelo HIV. Rev Saúde Pública 2014; 48:36-42.

20. Andrade RG, Iriart JAB. Estigma e discriminação: experiências de mulheres HIV positivo nos bairros populares de Maputo, Moçambique. Cad Saúde Pública 2015; 31:565-74.
21. French H, Greeff M, Watson MJ, Doak C. A Comprehensive HIV stigma-reduction and wellnessenhancement community intervention: a case study. J Assoc Nurses AIDS Care 2015; 26:81-96.

22. Adam P, Herzlich C. Sociologia da doença e da medicina. São Paulo: Editora EDUSC; 2001.

23. Salles M, Barros S. Representações sociais de usuários de um Centro de Atenção Psicossocial e pessoas de sua rede sobre doença mental e inclusão social. Saúde Soc 2013; 22:1059-71.

24. Scorsolini-Comin F, Santos M, Souza VL. Vivências e discursos de mulheres mastectomizadas: negociações e desafios do câncer de mama. Estud Psicol (Natal) 2009; 14:41-50.

25. Greene K, Banerjee SC. Disease-related stigma: comparing predictors of AIDS and cancer stigma. J Homosex 2006; 50:185-209.

26. Ferreira GCL, Silveira PS, Noto AR, Ronzani TM Implicações da relação entre estigma internalizado e suporte social para a saúde: uma revisão sistemática da literatura. Estud Psicol (Natal) 2014; 19:77-88.

27. Kippax S, Stephenson N, Parker R, Aggleton P. Between individual agency and structure in HIV prevention: understanding the middle ground of social practice. Am J Public Health 2013; 103:1367-75.

28. Paiva V, Ferguson L, Aggleton P, Mane P, Kelly-Hanku A, Giang LM, et al. The current state of play of research on the social, political and legal dimensions of HIV. Cad Saúde Pública 2015; 31:477-86. 


\section{Resumo}

O estudo analisa a relação entre o estigma relacionado à AIDS e os processos de discriminação antes do diagnóstico entre gestantes vivendo com HIVIAIDS. O trabalho de campo incluiu entrevistas sobre as trajetórias de vida de 29 gestantes recrutadas em serviços de AIDS no Rio de Janeiro, Brasil. A análise mostrou que antes do diagnóstico do HIV, as desigualdades sociais e de gênero vivenciadas por essas mulheres já haviam reduzido seu acesso a bens materiais e simbólicos que poderiam ter melhorado suas perspectivas educacio nais e de carreira, assim como, sua capacidade e autonomia no sentido de exercer seus direitos sexuais e reprodutivos. O diagnóstico de HIV provocava medo de julgamento moral e de desagregação nas redes de apoio sociais e familiares. Em função desses temores, as gestantes vivendo com HIV optam por ocultar o diagnóstico. É necessário que os serviços de saúde, ONGs e agências do governo colaborem para enfrentar os fatores que alimentam o estigma, tais como desigualdades socioeconômicas e de gênero, tabus e preconceitos relacionados à sexualidade, além de desenvolver ações parar empoderar as mulheres para redefinir a doença.

Síndrome de Imunodeficiência Adquirida; Estigma Social; Gestantes

\section{Resumen}

El estudio analiza la relación entre el estigma relacionado con el SIDA y los procesos de discriminación antes de su diagnóstico entre gestantes que viven con VIH/SIDA. El trabajo de campo incluyó entrevistas sobre las trayectorias de vida de 29 gestantes, inscritas en servicios de SIDA en Río de Janeiro, Brasil. El análisis mostró que, antes del diagnóstico del VIH, las desigualdades sociales y de género experimentadas por esas mujeres ya habian reducido su acceso a bienes materiales y simbólicos que podrían haber mejorado sus perspectivas educacionales y de carrera, así como su capacidad y autonomía, en el sentido de ejercer sus derechos sexuales y reproductivos. El diagnóstico de VIH provocaba miedo a un juicio moral y de desagregación en las redes de apoyo sociales y familiares. En función de esos temores, las gestantes viviendo con VIH optan por ocultar el diagnóstico. Es necesario que los servicios de salud, ONGs y agencias del gobierno colaboren para enfrentar los factores que alimentan el estigma, tales como desigualdades socioeconómicas y de género, tabús y prejuicios relacionados con la sexualidad, además de desarrollar acciones parar empoderar a las mujeres con el fin de redefinir la enfermedad.

Sindrome de Inmunodeficiencia Adquirida; Estigma Social; Mujeres Embarazadas
Submitted on $27 / J u l / 2015$

Final version resubmitted on $02 /$ Nov/2015 Approved on 26/Nov/2015 